\title{
The use of co-digested solid fraction as feedstock for biogas plants
}

\author{
Elio Dinuccio, Fabrizio Gioelli, Dalibor Cuk, Luca Rollè, Paolo Balsari \\ Department of Agriculture, Forestry and Food Science, University of Torino, Grugliasco (TO), Italy
}

\begin{abstract}
A comparative study was set up in order to assess the technical feasibility of the long-term reuse of the mechanically separated co-digested solid fraction as a feedstock for anaerobic digestion plants (ADP). The biogas yields of two feedstock mixtures (A and $\mathrm{B}$ ) were assessed in mesophilic conditions $\left(40^{\circ} \mathrm{C} \pm 2^{\circ} \mathrm{C}\right)$ using 6 lab-scale continuous stirredtank reactors. Feedstock mixture A (control) consisted of pig slurry (70\%), farmyard manure (4\%), sorghum silage (12\%) and maize silage (14\%). Feedstock mixture B was the same as the control plus the solid fraction derived from the mechanical separation of the output raw codigestate collected from the reactors. All reactors were fed simultaneously, three times a week, over a period of nine month. According to the study results, the reuse of the co-digested solid fraction as feedstock for ADP could increase the methane yield by approximately $4 \%$. However, ADP efficiency evaluation (e.g., daily yield of methane per $\mathrm{m}^{3}$ of digester) suggests limiting this practice to a maximum time period of 120 days.
\end{abstract}

\section{Introduction}

Anaerobic digestion of organic substrates for the production and transformation of biogas into electric and thermal energy is experiencing a period of strong growth in Italy. According to a recent survey (Fabbri et al., 2013), approximately 1000 agricultural anaerobic diges-

Correspondence: Elio Dinuccio, Department of Agriculture, Forestry and Food Science (DISAFA), University of Torino, via Leonardo da Vinci 44, 10095 Grugliasco (T0), Italy.

Tel. +39.0116708718 - Fax: +39.0116708591 .

E-mail: elio.dinuccio@unito.it

Key words: anaerobic digestion, biogas, mechanical separation, solid fraction.

Funding: this study was financed by the AGER foundation within the SEESPIG project (http://www.seespig.unimi.it) - grant $\mathrm{n}^{\circ} 2010-2220$, in the framework of the pig supply chain.

Received for publication: 15 July 2013.

Accepted for publication: 17 January 2014.

(C) Copyright E. Dinuccio et al., 2013

Licensee PAGEPress, Italy

Journal of Agricultural Engineering 2013; XLIV:208

doi:10.4081/jae.2013.208

This article is distributed under the terms of the Creative Commons Attribution Noncommercial License (by-nc 3.0) which permits any noncommercial use, distribution, and reproduction in any medium, provided the original author(s) and source are credited. tion plants (ADP) are currently running on the national territory with a total installed electrical capacity of $756 \mathrm{MW}$. These ADP are generally installed at livestock farms and are mostly fed with animal manure, energy crops and agricultural by-products. Co-digestate is the main final product of ADP. It contains mostly water, undigested organic matter and readily available inorganic compounds (e.g., nitrogen, phosphorus, potash) to crops. Due to the construction of the ADP often inside intensive livestock production units with insufficient arable land for nutrient recycling, export of nutrients to outside farm areas may be necessary to avoid excess load of nutrients, with special regards to nitrogen $(\mathrm{N})$. For such a reason, in many Italian anaerobic digestion plants, co-digestate is mechanically separated in order to obtain a liquid and a solid fraction (Dinuccio et al., 2010). In the liquid phase the greater amount of potassium and inorganic nitrogen is concentrated, whereas the solid fraction mainly contains organic compounds and phosphorus (Dinuccio et al., 2010). The liquid fraction is generally land applied near the ADP while the solid fraction is exported to outside farm areas or sold to other farmers. Nevertheless, the codigested solid fraction can still contain a high biogas and methane $\left(\mathrm{CH}_{4}\right)$ potential (Balsari et al., 2010), due to the presence of residual and undigested volatile solids (VS). Thus, it can be reused as ADP feedstock. Balsari et al. (2010), in a work carried out at a national level through batch trials, found specific $\mathrm{CH}_{4}$ yields of co-digested solid fraction ranging between 0.07 and $0.16 \mathrm{Nm}^{3} / \mathrm{kgVS}$. According to these figures they estimated that the reuse of the mechanically separated codigested solid fraction into the digester has the potential to improve the total $\mathrm{CH}_{4}$ production of the ADP by between $4 \%$ and $8 \%$, depending on ADP operating parameters [e.g., feedstock type and quality, organic loading rate (OLR), hydraulic retention time (HRT)] and the type of separator (e.g., screw press, one stage rotating separator) used to separate the raw co-digested slurry. Moreover, utilizing the co-digested solid fraction in this manner could reduce greenhouse gases and ammonia $\left(\mathrm{NH}_{3}\right)$ normally released (Dinuccio et al., 2013) during its storage. However, specific studies assessing the applicability of such an option in a continuous fed anaerobic digestion system are lacking. This paper presents the results of a laboratory scale experiment carried out with the objective to assess the technical feasibility of the long-term reuse of the mechanically separated co-digested solid fraction as a feedstock for ADP.

\section{Materials and methods}

\section{Biomasses collection and characterization}

Fresh samples of pig slurry, farmyard manure, sorghum silage and maize silage were collected at a selected full scale ADP operating in the Piemonte region (north western Italy), on the first working day of each month for the duration of the experimental period (270 days). The selected full scale ADP is a mesophilic $\left(40^{\circ} \mathrm{C}\right)$, completely stirred tank reactor with $0.5 \mathrm{MW}$ of installed electric power. It is fed with a mixture of pig slurry (70\%), farmyard manure (4\%), sorghum silage (12\%), maize silage (14\%). The OLR of the plant is $2.20 \mathrm{kgVS} / \mathrm{m}^{3} \mathrm{dig}$. day, and the HRT is approximately 40 days. Collected samples were 
stored at $5{ }^{\circ} \mathrm{C}$ prior to the anaerobic digestion tests. All biomasses were analysed in triplicate for $\mathrm{pH}$, total solids (TS), VS, total nitrogen (TN), total ammoniacal nitrogen (TAN), hemicelluloses (HC), celluloses (CE) and lignin (ADL). The $\mathrm{pH}$ was measured by a portable $\mathrm{pH}$ meter [Hanna Instruments HI 9026; Hanna Instruments S.r.l., Ronchi di Villafranca (PD), Italy] using a glass electrode combined with a thermal automatic compensation system. TS were determined after $24 \mathrm{~h}$ at $105^{\circ} \mathrm{C}$. VS were determined after $4 \mathrm{~h}$ at $550^{\circ} \mathrm{C}$ in a muffle furnace (AOAC, 2000). TN and TAN were analysed by the Kjeldahl standard method (AOAC, 2000). HC, CE and ADL were determined by the Van Soest methods (Van Soest et al., 1991).

\section{Continuous anaerobic digestion experiment}

The biogas yields of two different feedstock mixtures were compared: i) mixture A (control - the same of the selected full scale ADP): pig slurry (70\%) farmyard manure (4\%), sorghum silage (12\%), maize silage (14\%); ii) mixture B: the same mixture as the control plus all (100\%) the solid fraction obtained after mechanical separation of the output co-digestate collected from the digester.

The experiment was carried out under mesophilic conditions $\left(40^{\circ} \mathrm{C} \pm 2^{\circ} \mathrm{C}\right)$, within a temperature-controlled chamber, by using 6 identical lab-scale continuous fed stirred-tank reactors. Each reactor (Figure 1), cylindrical in shape, is made up of plexiglass, with a total volume of $6.5 \mathrm{~L}$. The biomass within the reactor is continuously mixed at a constant rate of about $4 \mathrm{rpm}$ by a vertical mixer connected to a geared motor installed on the top of reactor. The reactors are equipped with inlet and outlet ports for feeding and effluent discharge. A pipe situated at the top of the reactors is connected to Tedlar ${ }^{\circledR}$ (DuPont Co., Wilmington, DE, USA) gas bags by means of Tygon ${ }^{\circledR}$ (Saint-Gobain S.A., Courbevoie, France) tubing to collect the produced biogas.

The experiment lasted 270 days. At the beginning of the experiment (day 0 ), the reactors were inoculated with $5.5 \mathrm{~L}$ of co-digested slurry coming from the selected full scale ADP. Thereafter all reactors (named R1-R6) were fed simultaneously, three times a week, with a determined amount of tested biomasses, throughout the experimental period (270 days). Prior to feeding, an equivalent volume of digester content (raw co-digestate) was discharged.

\section{Start-up phase}

In the first part of the experiment all reactors were run with feedstock mixture A for 60 days in order to establish a stable digestion process and to ensure steady state conditions. During this period the reactors were operated with an OLR of $2.2 \mathrm{kgVS} / \mathrm{m}^{3}$ dig. day and a HRT of 40 days, in order to reproduce the same conditions of the selected full scale ADP.

Assessment of reuse of the co-digested solid fraction as a feedstock on the performances of anaerobic digesters

In the second part of the experiment (days 61-270), a set of three reactors (named R1-R3) continued to be fed with feedstock mixture A (control) and operated as during the start-up period (i.e., OLR=2.2 $\mathrm{kgVS} / \mathrm{m}^{3}$ dig. day; HRT $=40$ days) while the others three reactors (named R4-R6) were fed using feedstock mixture B (i.e., the same mixture as the control plus all the solid fraction obtained by mechanical separation of the output raw co-digestate collected three times a week from reactors R4-R6; Figure 2).

Mechanical separation of the raw co-digestate was performed by using a lab scale mechanical separator as described by Dinuccio et al. (2008). The total amount of separated raw co-digestate, as well as the amount of solid fraction recovered, were weighed and recorded.

Biogas and $\mathrm{CH}_{4}$ yields were measured three times a week throughout the experimental period. Biogas volume was determined connecting the Tedlar $^{\circledR}$ bags to a Ritter drum-type gas meter type TG05/5 instrument, while the biogas composition was determined using a Draeger XAM 7000 analyser with infrared sensors. The recorded data were normalized at standard temperature and pressure $\left(0^{\circ} \mathrm{C}\right.$ and 1013 $\mathrm{hPa}$ ) according to German Standard Procedure (VDI 4630, 2006). The specific yields of biogas and $\mathrm{CH}_{4}$ were subsequently expressed as normal $\mathrm{m}^{3}$ per $\mathrm{m}^{3}$ digester and day $\left(\mathrm{Nm}^{3} / \mathrm{m}^{3}\right.$ dig. day) or as normal $\mathrm{m}^{3}$ per $\mathrm{kg}$ of volatile solids daily fed into the digester ( $\mathrm{Nm}^{3} / \mathrm{kgVS}$ day). In order to assess the effect of the long-term reuse of the co-digested solid fraction as a feedstock on the performances of anaerobic digesters, the second part of the experiment (days 61-270) was divided into 7 periods of 30 days. During the experimental period the pH, TS and VS of raw codigestate and co-digested solid fraction were monitored monthly, while TN, TAN and fibres (HC, CE, ADL) were analysed two times: at the end

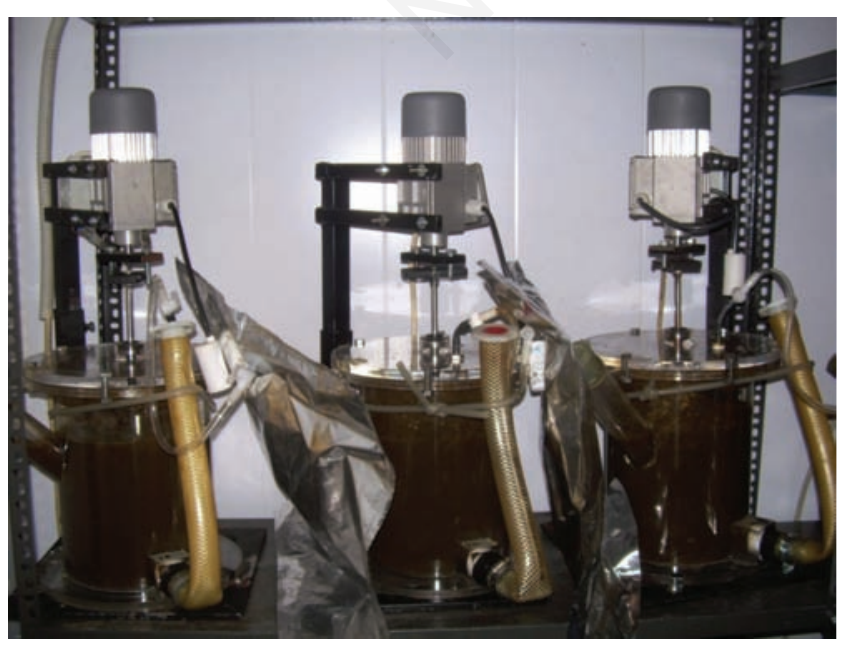

Figure 1. The lab-scale continuous fed stirred-tank reactors used for the trial.

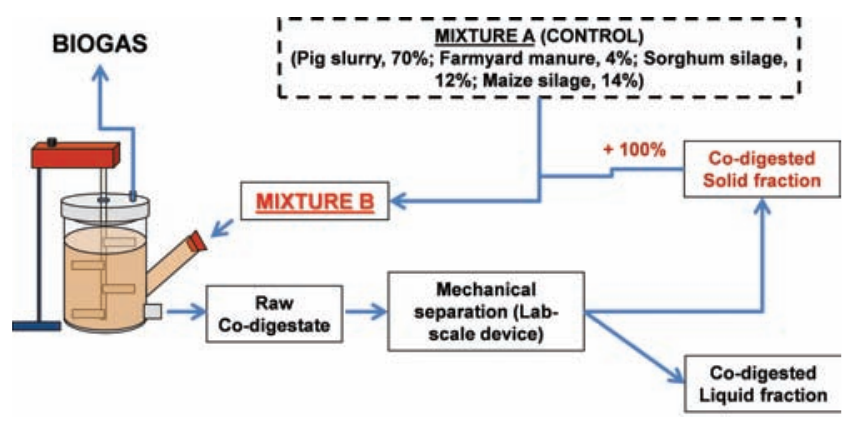

Figure 2. Feeding scheme of the reactors R4-R6. 
of start-up phase (day 60), and at the end of the trial (day 270). All parameters were analysed in triplicate using the same procedures as previously described for fresh biomasses. Data were analysed by analysis of variance procedure (ANOVA) followed by Tukey's means grouping tests. The level of significance was defined as a P-value below 0.05 .

\section{Results and discussion}

\section{Characterisation of fresh biomasses}

The main characteristics of fresh biomasses used for the trial are summarized in Table 1 . The TS content ranged from $1.13 \%$ in pig slurry to about $30 \%$ in maize silage, whereas the VS/TS ratio ranged from 0.68 to 0.96 . The TAN/TN ratio ranged from $7.43 \%$ (sorghum silage) to $78.8 \%$ (Farmyard manure). Maize silage had the lowest ADL content, whereas that of farmyard manure was the highest. The average amount of feedstock mixture A and feedstock mixture B used to feed the reactors during the investigation period resulted, respectively, $149 \pm 8.16$ and $162 \pm 10.7 \mathrm{~g} /$ reactor day.

\section{Continuous anaerobic digestion experiment}

\section{Start-up phase}

During the start-up phase (60 days) the average percentage of $\mathrm{CH}_{4}$ in biogas (Figure 3) gradually increased up to the greatest value (53.8\%) at day 13; then it stabilized around an average value of $52.4 \%$ (range 50.6-53.9\%). The average biogas yield followed a similar trend; this trend showed a peak $\left(1.49 \mathrm{Nm}^{3} / \mathrm{m}^{3}\right.$ dig. day) at day 18 followed by a steady state period (days 19-60) during which the biogas yield averaged 1.40 (range $1.32-1.48$ ) $\mathrm{Nm}^{3} / \mathrm{m}^{3} \mathrm{dig}$. day. During the 41 days steady state period, the average daily $\mathrm{CH}_{4}$ produced by reactors $\mathrm{R} 1-\mathrm{R} 6$ ranged between 0.313 and $0.353 \mathrm{Nm}^{3} / \mathrm{kgVS}$, comparable to values measured by Gioelli et al. (2012) during a 12 months period of monitoring of the selected full scale ADP; the degree of VS degraded during the anaerobic digestion process resulted $64 \%$. Investigations of 41 biogas plants in Austria by Hopfner-Sixt and Amon (2007) found $\mathrm{CH}_{4}$ yields from co-fer-

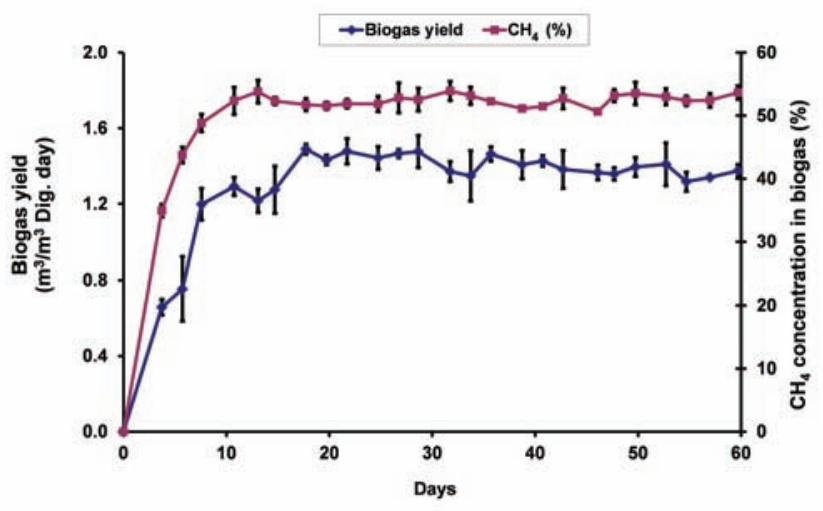

Figure 3. Specific biogas yield and methane concentration recorded from reactors $\mathrm{R} 1-\mathrm{R} 6$ during the start-up phase (days 0 60). Error bars indicate standard deviation $(\mathrm{N}=6)$.

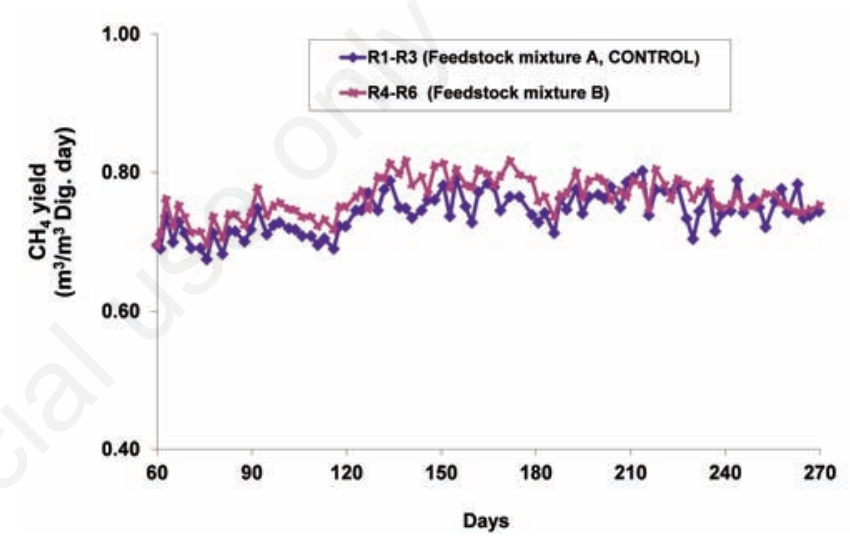

Figure 4. Average volumetric methane yields recorded from day 60 (end of the start-up phase) to day 270 (end of the trial) from reactors R1-R3 (feedstock mixture A, control) and from reactors R4-R6 (feedstock mixture B). $\mathrm{N}=3$; standard deviation removed for clarity.

Table 1. Main chemical and physical characteristics of the fresh biomasses used in the trial (standard deviation in parentheses, $\mathrm{n}=27$ ).

\begin{tabular}{lcccc} 
& Maike silage & Sorghum silage & Farmyard manure & \\
pH & 3.75 & 3.96 & 8.49 & 7.26 \\
& $(0.22)$ & $(0.19)$ & $(0.17)$ & $(0.25)$ \\
TS (\%) & 30.5 & 27.6 & 22.3 & 1.13 \\
& $(2.96)$ & $(2.46)$ & $(2.37$ & $(0.52)$ \\
\hline VS (\%TS) & 95.5 & 91.2 & 78.7 & 67.6 \\
TN (\%) & $(0.96)$ & $(1.05)$ & $(4.01)$ & $(4.38)$ \\
& 0.34 & 0.37 & 0.48 & 0.15 \\
TAN (\%) & $(0.10)$ & $(0.09)$ & $(0.09)$ & $(0.07)$ \\
& 0.03 & 0.03 & 0.38 & 0.11 \\
HC (\%) & $(0.02)$ & $(0.01)$ & $(0.06)$ & $(0.04)$ \\
& 7.82 & 6.24 & 4.20 & n.d. \\
CE (\%) & $(0.74)$ & $(0.12)$ & $(0.94)$ & 7.01 \\
& 8.16 & 9.15 & $(0.41)$ & n.d. \\
ADL (\%) & $(0.63)$ & $(0.72)$ & 2.67 & n.d. \\
& 0.99 & 1.41 & $(0.84)$ & \\
\end{tabular}

TS, total solids; VS, volatile solids; TN, total nitrogen; TAN, total ammoniacal nitrogen; HC, hemicelluloses; CE, celluloses; ADL, lignin; n.d., not detected. 
mentation of animal manure and energy crops up to $0.39 \mathrm{Nm}^{3} / \mathrm{kgVS}$, with VS degradation rates of $78-84 \%$. The lower degree of degradation found in this study can be explained by the shorter HRT ( 40 days) of the reactors, which is similar to that of the selected full scale ADP but lesser than the minimum HRT of 45-60 days recommended in the literature (e.g., Öchsner and Helffrich, 2005) for an optimal degradation of VS content in energy crops.

Assessment of reuse of the co-digested solid fraction as a feedstock on the performances of anaerobic digesters

In Table 2 are shown the main chemical and physical characteristics of the co-digested solid fraction obtained by mechanical separation of raw co-digestate from reactors R4-R6, and used as feedstock for the reactors during the test. Total solids content of co-digested solid fraction ranged from 16.4 to 18.1 ; VS and TS ratio resulted to be always higher than 0.85 suggesting a residual availability of undigested organic matter. However, the concentrations of $\mathrm{HC}$ and $\mathrm{CE}$ in co-digested solid fraction tended to decrease over time (Table 2), while, in contrast, the concentration of ADL increased, resulting $1.43 \%$ at day 60 (end of start-up phase) and 5.03\% at day 270 (end of the experiment). The average amount of raw co-digestate recorded from reactors R1-R3 (feedstock mixture A) and from reactors R4-R6 (feedstock mixture B) over the investigation period resulted, respectively, $135 \pm 7.43$ and $145 \pm 9.03 \mathrm{~g} /$ reactor day. The separation efficiency in terms of mass (i.e., the relative amount of co-digested solid fraction obtained by mechanical separation of the raw co-digestate) of the used lab-scale mechanical separator resulted, on average, $9.70 \%$ (range $8.70-10.6 \%$ ).

Figure 4 depicts the average $\mathrm{CH}_{4}$ yields recorded from each feedstock mixture (A and B) during the second part (days 61-270) of the experiment. During this 210 days period, the average volumetric $\mathrm{CH}_{4}$ produced by mixture A (control, reactors R1-R3) ranged between 0.674 and $0.802 \mathrm{Nm}^{3} / \mathrm{m}^{3}$ dig. day, reflecting the variability of the characteristics of fresh biomasses (Table 1) collected at the selected ADP during the experiment. The specific $\mathrm{CH}_{4}$ yields, expressed as $\mathrm{Nm}^{3} / \mathrm{kgVS}$ (Table 3 ), obtained over the experimental period by feedstock mixture B (reactors R4-R6) were, on average, 17\% lower than those recorded from the control (feedstock mixture A reactors R1-R3). However, the average daily volumetric $\mathrm{CH}_{4}$ yields by mixture B (reactors R4-R6) (Figure 4) were generally higher than those obtained by mixture A for most of the experimental period. The reuse of the co-digested solid fraction in reactors R4-R6 gradually increased the average volumetric $\mathrm{CH}_{4}$ production rate from 0.728 (days 61-90) to 0.791 (days 151-180) $\mathrm{Nm}^{3} / \mathrm{m}^{3}$ dig. day (Table 4). The latter value corresponds to a significant $(\mathrm{P}<0.05)$ increase of $4.36 \%$ when compared to the average volumetric $\mathrm{CH}_{4}$ pro- duction rate $\left(0.758 \mathrm{Nm}^{3} / \mathrm{m}^{3}\right.$ dig. day) recorded from reactors $\mathrm{R} 1-\mathrm{R} 3$ (control). After this period such differences did, however, start to decrease, dropping to a value of $+0.28 \%$ during the last 30 days of trial (Table 4).

The $\mathrm{pH}$ values of the raw co-digestate recorded over time (Figure 5A) suggests a regular course of the anaerobic digestion process within all the reactors. The average $\mathrm{pH}$ values of co-digestate from reactors $\mathrm{R} 4-\mathrm{R} 6$ ranged between 7.4 and 7.7, within the optimum range (6.5-7.8) for the adequate growth of anaerobic microorganisms (Liu et al., 2008). This observation indicates that the process adapted well to the introduction of the co-digested solid fraction as co-substrate, as $\mathrm{pH}$ fluctuation is a widely used indicator of process stress in anaerobic reactors (Ward et al., 2008). However, the concentration of TAN (Table 5) in raw co-digestate from reactors R4-R6 has shown the tendency to increase, resulting $0.14 \%$ at day 60 (end of start-up phase) and $0.20 \%$ at day 270 (end of the experiment), indicating the possibility of inhibition on the activity of microorganisms. Free ammonia has been suggested to be the main cause of inhibition in anaerobic digesters due to its high membrane permeability (Kroeker et al., 1979; de Baere et al., 1984). Ammonia inhibition was reported to occur above $\mathrm{pH} 7.4$ in the range of $1500-3000 \mathrm{mgTAN} / \mathrm{L}$, whereas at concentrations in excess of $3000 \mathrm{mgTAN} / \mathrm{L}$, ammonia was claimed to be toxic irrespective of $\mathrm{pH}$ (Van Velsen, 1979; Koster and Lettinga, 1984). A remarkable increase over time of hemicelluloses, celluloses and lignin content of raw co-digestate from reactors R4-R6 was also observed (Table 5). Lignin is not degradable under anaerobic conditions and may prevent microbial access to hemicelluloses and celluloses (Mussatto et al., 2008). On average, the concentration of TS (Figure 5B) and VS (Figure 5C) in raw co-digestate from reactors R4-R6 resulted, respectively, $15.5 \%$ and $18.9 \%$ higher than the concentration in raw codigestate from reactors (R1-R3). An average VS removal efficiency (Figure 5D) of $66.0 \%$ and $63.6 \%$, respectively, for reactors R1-R3 and reactors R4-R6 was calculated.

\section{Conclusions}

The results obtained in this laboratory-scale study confirm that the co-digested solid fraction can still contain a high biogas and methane potential. The reuse of the co-digested solid fraction as feedstock for ADP seems to be an interesting option. Under the specific laboratory conditions adopted in this study, the long-term reuse of the co-digested solid fraction into the digester improved the total $\mathrm{CH}_{4}$ production by approximately 4\%. However, after 120 days of continuous recirculation

Table 2. Main chemical and physical characteristics of the co-digested solid fraction obtained by mechanical separation of raw co-digestate from reactors $\mathrm{R} 4-\mathrm{R} 6$.

\begin{tabular}{lcccccccc} 
Days from the beginning of the experiment & pH & TS (\%) & VS (\%TS) & TN (\%) & TAN (\%) & HC (\%) & CE (\%) & ADL (\%) \\
60 (end of start-up phase) & 8.26 & 17.2 & 85.7 & 0.43 & 0.14 & 5.86 & 8.51 & - \\
90 & 8.30 & 18.1 & 86.6 & - & - & - & - \\
\hline 120 & 8.18 & 17.6 & 88.8 & - & - & - & - \\
150 & 8.30 & 16.5 & 86.9 & - & - & - & - \\
180 & 8.21 & 16.6 & 87.6 & - & - & - & - \\
210 & 8.14 & 16.4 & 86.9 & - & - & - & - \\
240 & 8.23 & 17.2 & 87.5 & - & - & - & - \\
270 (end of the experiment) & 8.18 & 17.9 & 86.5 & 0.53 & 0.15 & 3.75 & - \\
\hline
\end{tabular}

TS, total solids; VS, volatile solids; TN, total nitrogen; TAN, total ammoniacal nitrogen; HC, hemicelluloses; CE, celluloses; ADL, lignin. 
Table 3. Average specific methane yields recorded during the experiment from reactors R1-R3 (feedstock mixture A, control) and from reactors R4-R6 (feedstock mixture B). Standard deviation in parentheses $(n=36)$.

\begin{tabular}{|c|c|c|c|}
\hline Experimental period (days) & $\begin{array}{c}\text { R1-R3 } \\
\left(\mathrm{Nm}^{3} / \mathrm{kgVS}\right)\end{array}$ & $\begin{array}{c}\mathrm{R} 4-\mathrm{R} 6 \\
\left(\mathrm{Nm}^{3} / \mathrm{kgVS}\right)\end{array}$ & Significance (P) \\
\hline $61-90$ & $\begin{array}{c}0.320^{\mathrm{a}} \\
(0.008)\end{array}$ & $\begin{array}{c}0.281^{b} \\
(0.007)\end{array}$ & $<0.00$ \\
\hline $91-120$ & $\begin{array}{c}0.325^{\mathrm{a}} \\
(0.007) \\
\end{array}$ & $\begin{array}{l}0.287^{\mathrm{b}} \\
(0.006) \\
\end{array}$ & $<0.00$ \\
\hline $121-150$ & $\begin{array}{c}0.344^{\mathrm{a}} \\
(0.008)\end{array}$ & $\begin{array}{c}0.304^{\mathrm{b}} \\
(0.008)\end{array}$ & $<0.00$ \\
\hline $151-180$ & $\begin{array}{c}0.34^{\mathrm{a}} \\
(0.010)\end{array}$ & $\begin{array}{l}0.303^{\mathrm{b}} \\
(0.006)\end{array}$ & $<0.00$ \\
\hline $181-210$ & $\begin{array}{c}0.343^{\mathrm{a}} \\
(0.009)\end{array}$ & $\begin{array}{l}0.295^{\mathrm{b}} \\
(0.007)\end{array}$ & $<0.00$ \\
\hline $211-240$ & $\begin{array}{c}0.344^{\mathrm{a}} \\
(0.014)\end{array}$ & $\begin{array}{r}0.293^{\mathrm{b}} \\
(0.007)\end{array}$ & $<0.00$ \\
\hline $241-270$ & $\begin{array}{c}0.342^{\mathrm{a}} \\
(0.009)\end{array}$ & $\begin{array}{c}0.284^{\mathrm{b}} \\
(0.003)\end{array}$ & $<0.00$ \\
\hline
\end{tabular}

VS, volatile solids. a,b Data in a row followed by a different letter differ significantly $(\mathrm{P}<0.05)$.

Table 4. Average volumetric methane production rates recorded during the experiment from reactors R1-R3 (feedstock mixture A, control) and from reactors R4-R6 (feedstock mixture B). Standard deviation in parentheses $(n=36)$.

\begin{tabular}{|c|c|c|c|}
\hline \multirow[t]{2}{*}{ Experimental period (days) } & \multicolumn{2}{|c|}{ Reactors } & \multirow[t]{2}{*}{ Significance (P) } \\
\hline & $\begin{array}{c}\text { R1-R3 } \\
\left(\mathrm{Nm}^{3} / \mathrm{m}^{3} \text { digester and day) }\right.\end{array}$ & $\begin{array}{l}\text { R4-R6 } \\
\text { ligester and day) }\end{array}$ & \\
\hline $61-90$ & $\begin{array}{l}0.704^{\mathrm{b}} \\
(0.018)\end{array}$ & $\begin{array}{l}0.728^{\mathrm{a}} \\
(0.019)\end{array}$ & 0.002 \\
\hline $91-120$ & $\begin{array}{l}0.715^{b} \\
(0.015)\end{array}$ & $\begin{array}{l}0.743^{\mathrm{a}} \\
(0.016)\end{array}$ & $<0.000$ \\
\hline $121-150$ & $\begin{array}{l}0.756^{\mathrm{b}} \\
(0.017)\end{array}$ & $\begin{array}{c}0.789^{\mathrm{a}} \\
(0.021)\end{array}$ & $<0.000$ \\
\hline $151-180$ & $\begin{array}{l}0.758^{b} \\
(0.022)\end{array}$ & $\begin{array}{l}0.791^{\mathrm{a}} \\
(0.016)\end{array}$ & $<0.000$ \\
\hline $181-210$ & $\begin{array}{c}0.755^{\mathrm{a}} \\
(0.020)\end{array}$ & $\begin{array}{c}0.771^{\mathrm{a}} \\
(0.018)\end{array}$ & 0.066 \\
\hline $211-240$ & $\begin{array}{c}0.757^{\mathrm{a}} \\
(0.030)\end{array}$ & $\begin{array}{c}0.774^{\mathrm{a}} \\
(0.018)\end{array}$ & 0.101 \\
\hline $241-270$ & $\begin{array}{l}0.752^{\mathrm{a}} \\
(0.020)\end{array}$ & $\begin{array}{l}0.754^{\mathrm{a}} \\
(0.009)\end{array}$ & 0.737 \\
\hline
\end{tabular}

${ }^{\mathrm{a}, \mathrm{b}}$ Data in a row followed by a different letter differ significantly $(\mathrm{P}<0.05)$.

Table 5. Main chemical and physical characteristics of the raw co-digestate recorded at day 60 (end of the start-up phase) and at day 270 (end of the trial) from reactors R1-R3 (feedstock mixture A, control) and from reactors R4-R6 (feedstock mixture B). Standard deviation in parentheses $(n=3)$.

\begin{tabular}{|c|c|c|c|c|c|c|c|c|c|}
\hline $\begin{array}{l}\text { Days from the star } \\
\text { of the experiment }\end{array}$ & Reactors & $\mathrm{pH}$ & $\begin{array}{l}\text { TS } \\
(\%)\end{array}$ & $\begin{array}{l}\text { VS } \\
\text { (\%TS) }\end{array}$ & $\begin{array}{l}\text { TN } \\
(\%)\end{array}$ & $\begin{array}{l}\text { TAN } \\
(\%)\end{array}$ & $\begin{array}{l}\mathrm{HC} \\
(\%)\end{array}$ & $\begin{array}{l}\mathrm{CE} \\
(\%)\end{array}$ & $\begin{array}{l}\text { ADL } \\
(\%)\end{array}$ \\
\hline 60 (end of start-up phase) & $\mathrm{R} 1-\mathrm{R} 6$ & $\begin{array}{l}7.68 \\
(0.07)\end{array}$ & $\begin{array}{l}4.66 \\
(0.10)\end{array}$ & $\begin{array}{c}70.0 \\
(0.76)\end{array}$ & 0.23 & 0.14 & 0.47 & 0.26 & 0.21 \\
\hline 270 (end of experiment) & $\begin{array}{l}\text { R1-R3 } \\
\text { R4-R6 }\end{array}$ & $\begin{array}{c}7.53 \\
(0.07) \\
7.45 \\
(0.07)\end{array}$ & $\begin{array}{c}5.09 \\
(0.19) \\
6.33 \\
(0.25)\end{array}$ & $\begin{array}{c}72.8 \\
(1.03) \\
75.4 \\
(0.89)\end{array}$ & $\begin{array}{c}0.24 \\
(0.03) \\
0.24 \\
(0.02)\end{array}$ & $\begin{array}{c}0.15 \\
(0.01) \\
0.20 \\
(0.01)\end{array}$ & $\begin{array}{c}0.84 \\
(0.14) \\
1.90 \\
(0.11)\end{array}$ & $\begin{array}{c}0.73 \\
(0.12) \\
0.93 \\
(0.09)\end{array}$ & $\begin{array}{l}1.13 \\
(0.34) \\
2.23 \\
(0.15)\end{array}$ \\
\hline
\end{tabular}

TS, total solids; VS, volatile solids; TN, total nitrogen; TAN, total ammoniacal nitrogen; HC, hemicelluloses; CE, celluloses; ADL, lignin. 
A

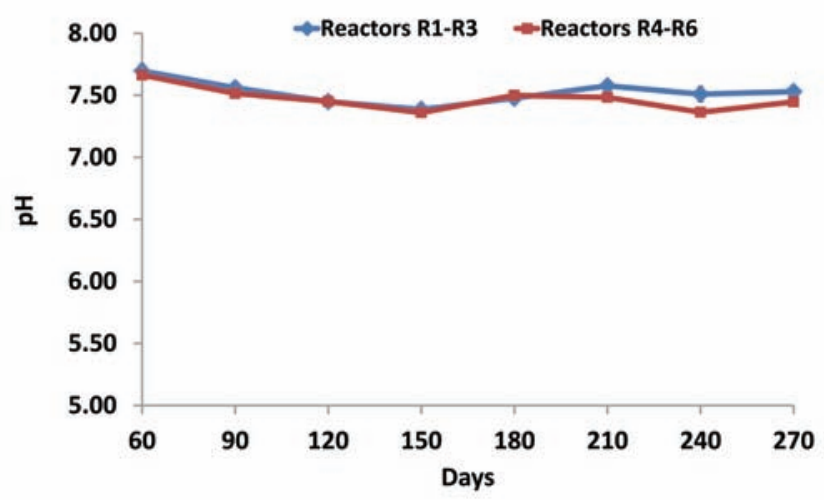

B

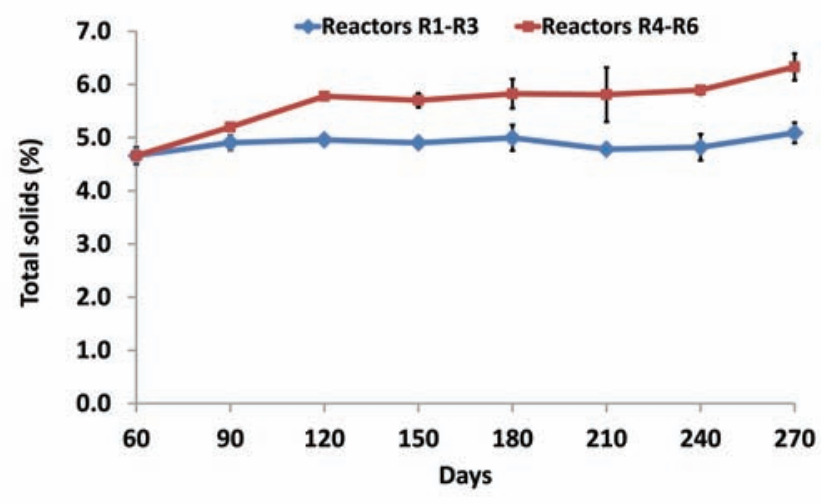

C

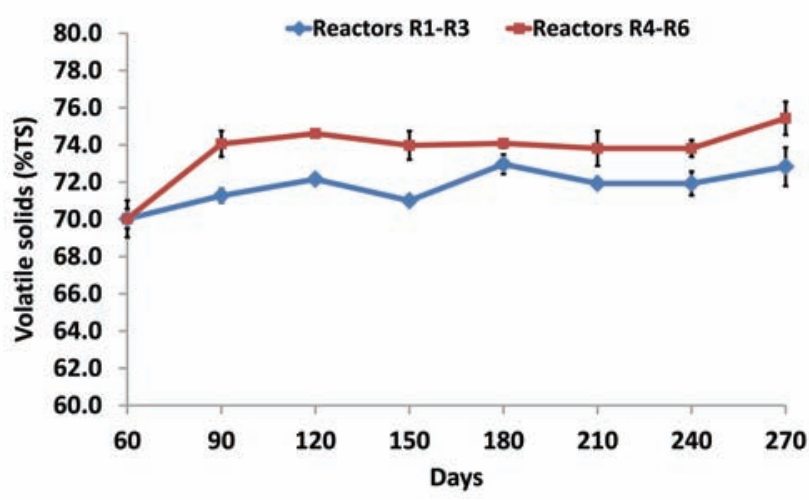

D

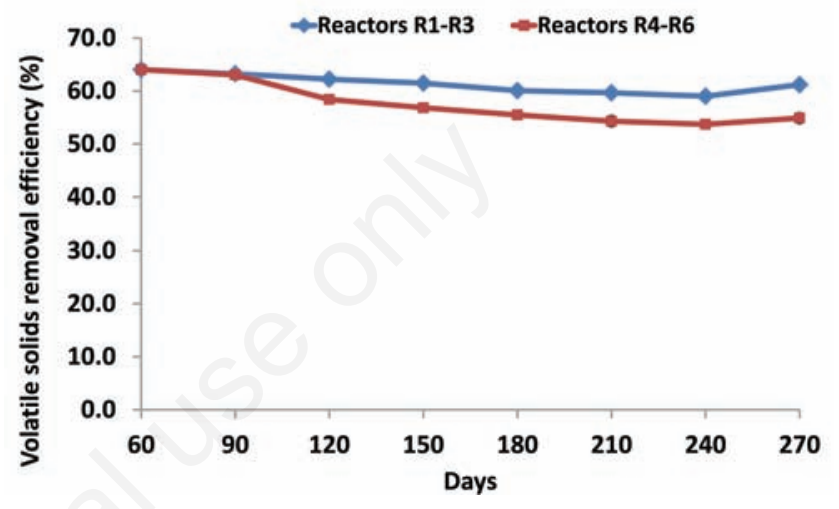

Figure 5. Evolution of $\mathrm{pH}(\mathrm{A})$, total solids (B) and volatile solids (C) content in raw co-digestate and volatile solids removal efficiencies (D) measured from reactors R1-R3 and reactors R4-R6.

of the co-digested solid fraction the volumetric $\mathrm{CH}_{4}$ yield of the reactors started to decline, mainly due to the accumulation of recalcitrant organic fibres (e.g., lignin), which are compounds minimally digestible by anaerobic microorganisms. Therefore it is suggested to restrict this practice for limited periods of time, monitoring regularly the productivity of the ADP (e.g., daily yield of biogas and methane per $\mathrm{m}^{3}$ of digester) and the key process parameters (e.g., $\mathrm{pH}$ and TAN concentration in raw co-digestate) in order to maintain such variables steady and within the optimal ranges for the adequate growth of anaerobic microorganisms.

\section{References}

AOAC. 2000. Official methods of analysis, 15th ed. Association of Official Analytical Chemists, Arlington, VA, USA.

Balsari P., Gioelli F., Menardo S., Paschetta E. 2010. The (re)use of mechanical separated solid fraction of digested or not digested slurry in anaerobic digestion plants. In: C.S.C. Cordovil and L. Ferreira (eds.) Proc. 14th Ramiran Int. Conf., Lisboa, Portugal. Available from: http://www.ramiran.net/ramiran2010/docs/Ramiran 2010_0256_final.pdf

de Baere L.A., Devocht M., Van Assche P., Verstraete W. 1984. Influence of high $\mathrm{NaCl}$ and $\mathrm{NH} 4 \mathrm{Cl}$ salt levels on methanogenic associations. Water Res. 18:543-8.

Dinuccio E., Balsari P., Berg, W. 2008. Gaseous emissions from the stor- age of untreated slurries and the fractions obtained after mechanical separation. Atmos. Environ. 42:2448-59.

Dinuccio E., Cuk D., Rollè L., Gioelli F., Balsari P. 2013. GHG emissions from the storage of the liquid and solid fractions of co-digested pig slurry. In Proc. Int. Conf. on Greenhouse Gases and Animal Agriculture (GGAA), Dublin, Ireland. Electronic Edition.

Dinuccio E., Paschetta E., Gioelli F., Balsari P. 2010. Efficiency of mechanical separation of digested and not digested slurry. In: C.S.C. Cordovil and L. Ferreira (eds.), Proc. 14th Ramiran Int. Conf., Lisboa, Portugal. Available from: http:/www.ramiran.net/ ramiran2010/docs/Ramiran2010_0229_final.pdf

Fabbri C., Labartino N., Manfredi S., Piccinini S. 2013. Biogas, il settore è strutturato e continua a crescere. L'Informatore Agrario 11:11-6.

Gioelli F., Balsari P., Dinuccio E. 2012. Anaerobic digestion in northern Italy: the situation in Piemonte Region. In Proc. CIGRAgEng Conf., Valencia, Spain. Available from: http://cigr.ageng2012.org/images/ fotosg/tabla_137_C1298.pdf

Hopfner-Sixt K., Amon T. 2007. Monitoring of agricultural biogas plants - mixing technology and specific values of essential process parameters. In Proc. 15th European Biomass Conference \& Exhibition, Berlin, Germany. Available from: http://www.nas.boku.ac.at/ uploads/media/Monitoring_biogasplants_berlin.pdf

Koster I.W., Lettinga G. 1984. The influence of ammonium-nitrogen on the specific activity of palletized methanogenic sludge. Agric. Wastes 9:205-16.

Kroeker E.J., Schulte D.D., Sparling A.B., Lapp H.M. 1979. Anaerobic treatment process stability. J. Water Pollut. Control Fed. 51:718-27.

Liu C., Yuan X., Zeng G., Li W., Li J. 2008. Prediction of methane yield 
at optimum $\mathrm{pH}$ for anaerobic digestion of organic fraction of municipal solid waste. Bioresour. Technol. 99:882-8.

Mussatto S.I., Fernandes M., Milagres A.M.F., Roberto I.C. 2008. Effect of hemicellulose and lignin on enzymatic hydrolysis of cellulose from brewer's spent grain. Enzyme Microb. Technol. 43:124-9.

Öchsner H., Helffrich D., 2005. Technische Anforderungen an landwirschaftliche Biogsanlagen bei der Vergärung Nachwachsender Rohstoffe, VDI-Richtlinnien 2005, VDI-Berichte 1872.

Van Soest P.J., Robertson J.B., Lewis B.A. 1991. Methods for dietary fiber, neutral-detergent fiber and non-starch polysaccharides in relation to animal nutrition. J. Dairy Sci. 74:3583-97.

Van Velsen A.F.M. 1979. Adaptation of methanogenic sludge to high ammonia-nitrogen concentrations. Water Res. 13:995-9.

VDI (Verein Deutscher Ingenieure). 2006. VDI4630: Fermentation of organic materials, characterisation of substrate, sampling, collection of material data, fermentation tests. VDI Gesellschaft Energietechnik, Düsseldorf, Germany.

Ward A.J., Hobbs P.J., Holliman P.J., Jones D.L. 2008. Optimisation of the anaerobic digestion of agricultural resources. Bioresour. Technol. 99:7928-40. 